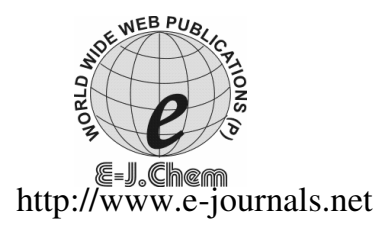

ISSN: 0973-4945; CODEN ECJHAO

E-Journal of Chemistry 2011, 8(1), 470-478

\title{
Syntheses, Spectral and Antifungal Studies of Some Metal Complexes Derived from a Macrocyclic Ligand
}

\author{
P.VENKATESWAR RAO*, S.AMMANNI and S.KALIDASU \\ Department of Chemistry, Nizam College, (Osmania University) \\ Hyderabad -500001. A.P. India \\ pallapothulav@gmail.com
}

Receivd 17 March 2010; Accepted 23 May 2010

\begin{abstract}
A new macrocyclic ligand 1-[5-(1-\{2-[1-(5-acetyl-2,4-dihydroxyphenyl)-ethylideneamino]-phenylimino)-ethyl)-2,4 dihydroxy-phenyl]-ethanone was prepared by condensation of ethanolic solutions of 4,6- diacetyl resorcinol and $o$-phenylenediamine. The ligand was characterized by ${ }^{1} \mathrm{H}-\&{ }^{13} \mathrm{C}$ - NMR, IR, Mass spectral data and analytical data. Metal complexes with this new macrocyclic ligand have been prepared with $\mathrm{VO}(\mathrm{IV}), \mathrm{Mn}(\mathrm{II}), \mathrm{Fe}(\mathrm{II}), \mathrm{Co}(\mathrm{II}), \mathrm{Ni}(\mathrm{II}), \mathrm{Cd}(\mathrm{II})$ and $\mathrm{Cu}$ (II). The metal chelates were characterized by elemental analyses, Molar conductance measurements, Magnetic susceptibility measurements, IR, UV Vis spectra. The ligand and the complexes were screened for anti fungal activity against Aspergillus terreus. The order of inhibition has been found to be $\mathrm{Cu}(\mathrm{II})>\mathrm{Cd}(\mathrm{II})$ $>\mathrm{Co}$ (II) $>\mathrm{VO}$ (IV) $>\mathrm{Fe}$ (II) $>\mathrm{Ni}$ (II) $>\mathrm{Mn}$ (II) $>$ Ligand.
\end{abstract}

Keywords: 4, 6-Diacetyl resorcinol, o-Phenylenediamine, Antifungal activity, Aspergillus terreus

\section{Introduction}

Metal Complexes with macrocyclic ligands have been very much useful in various biological fields ${ }^{1,2}$. Nature provides countless number of examples in this respect ${ }^{3}$. Metal complexes of azomethines played a major role in the development of coordination chemistry ${ }^{4}$. Macrocyclic ligands possessing nitrogen, oxygen and sulphur as donor atoms show significant antifungal, antibacterial and anti cancer activities besides these activities, some complexes also show catalytic property ${ }^{5-9}$. Some drugs upon complexation have increased their activity ${ }^{10-11}$. Some platinum complexes show anti tumor activity. These chelates interact with DNA and inhibit tumors ${ }^{12,13}$. In view of the above physiological activities, it is planned to synthesize a new macrocyclic ligand such as 1-[5-(1-\{2-[1-(5-acetyl-2,4-dihydroxyphenyl)-ethylideneamino]-phenyl imino)-ethyl-2,4 dihydroxy- phenyl ]- ethanone and its various complexes with $\mathrm{VO}(\mathrm{IV}), \mathrm{Mn}(\mathrm{II}), \mathrm{Fe}(\mathrm{II}), \mathrm{Co}(\mathrm{II}), \mathrm{Ni}(\mathrm{II}), \mathrm{Cd}(\mathrm{II})$ and $\mathrm{Cu}(\mathrm{II})$ and these compounds are to be screened for their antifungal activities. 


\section{Experimental}

All the chemicals used were analaR grade. All the solvents were purified by reported methods before use ${ }^{14}$. Double distilled water has been used where ever necessary. 4, 6- Diacetyl resorcinol was prepared by reported procedure ${ }^{15}$.

Melting points were determined with Bock Monoscope Wreck NR instrument. Electrical conductivity of the metal complexes was studied at room temperature with freshly prepared solutions in DMSO using Digisun Conductometer Model DI 909. UV Visible spectra were recorded on a UV Visible near IR Varian Cary 5E instrument. IR spectra $(\mathrm{KBr}$ discs) were recorded on a Bruker IFS-66V FT IR spectrophotometer. ${ }^{1} \mathrm{H}$ NMR spectra were recorded on Bruker Avance $300 \mathrm{MHz}$ spectrometer using TMS as standard. ${ }^{13} \mathrm{C}$ NMR spectra were also recorded in DMSO- $\mathrm{d}_{6}$ on a Bruker $300 \mathrm{MHz}$ NMR spectrometer. ESI mass spectrum was recorded on LC MSD Trap SL mass spectrometer. Metal estimations were carried out using a Varian Spectra AA 20 atomic absorption spectrometer. The magnetic susceptibility measurements were carried out on a Faraday Balance at room temperature using. $\mathrm{Hg}\left[\mathrm{Co}(\mathrm{SCN})_{4}\right]$ as calibrant. $\mathrm{C}, \mathrm{H}, \mathrm{N}$ analyses were carried out on a Heraeus $\mathrm{CHN}$ rapid analyzer.

\section{Preparation of the ligand}

The new ligand 1-[5-(1-\{2-[1-(5-acetyl-2,4-dihydroxy-phenyl) ethyl ideneamino] phenylimino $\}$ ethyl)-2,4dihydroxyphenyl]ethanone was prepared by the condensation of 4,6-diacetyl resorcinol with $o$-phenylenediamine in the ratio 2:1 (Figure 1). 4,6-Diacetyl resorcinol (2 m mol, $0.388 \mathrm{~g}$ ) was dissolved in $10 \mathrm{~mL}$ of methanol. $o$-Phenylenediamine $(1 \mathrm{mmol}, 0.108 \mathrm{~g}$ ) was dissolved in $10 \mathrm{~mL}$ of methanol separately. Sodium acetate $(1 \mathrm{~m} \mathrm{~mol}, 0.136 \mathrm{~g})$ was dissolved in double distilled water. All the three solutions were mixed in $50 \mathrm{~mL}$ round bottom flask and were refluxed on a mantle for half an hour. The color of the reaction mixture was changed to yellow. The solution was refluxed for a period of another three hours. Upon cooling overnight a yellow crystalline product was separated out. It was recrystallized from methanol, m.p. $202{ }^{\circ} \mathrm{C}$. (Yield 60\%)

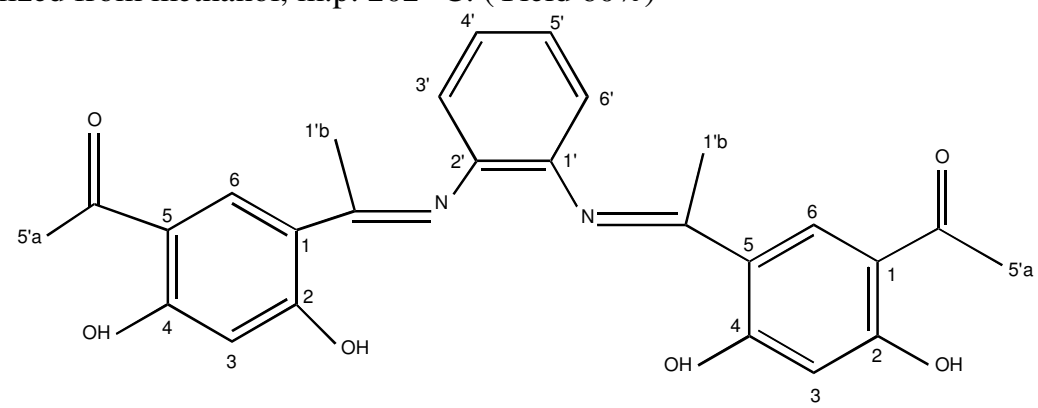

Figure 1. 1-[5-(1-\{2-[1-(5-Acetyl-2,4-dihydroxy-phenyl)-ethylideneamino]phenylimino $\}$ ethyl)-2,4 dihydroxy phenyl]ethanone

\section{Synthesis of metal complexes}

The metal chelates were prepared by refluxing the methanolic solutions of the respective metal(II) chlorides (1 m mol in $10 \mathrm{~mL}$ of methanol) [except in $\mathrm{VO}(\mathrm{IV})$ and $\mathrm{Fe}$ (II) complexes where in aqueous methanolic solutions of vanadyl sulphate and ferrous ammonium sulphate were used] and the ligand 1-[5-(1-\{2-[1-(5-acetyl-2,4-dihydroxyphenyl)-ethylideneamino]phenylimino ethyl)-2,4 dihydroxy phenyl]ethanone ( $1 \mathrm{~m} \mathrm{~mol}, 0.460 \mathrm{~g}$, in $10 \mathrm{~mL}$ of methanol) for about $4-5 \mathrm{~h}$ on a water bath. The $\mathrm{pH}$ of the reaction mixture was 
adjusted to 7-8 using ammonia solution. Upon cooling overnight the metal chelates were separated out. These were filtered by suction, washed with methanol followed by petroleum ether and dried in vacuum at $60-80{ }^{\circ} \mathrm{C}$.

\section{Results and Discussion}

The analytical data of the ligand and their metal complexes are given in the Table $1 \& 2$. This is in agreement with the proposed structures of the ligand and its complexes. All the metal chelates are colored. They are stable to air and moisture. The complexes are decomposed around $250-300{ }^{\circ} \mathrm{C}$. They are insoluble in water. But they are soluble in organic solvents like ethanol, DMF, DMSO and dioxane. Molar conductance measurements in DMSO solution indicate that they are non electrolytic in nature ${ }^{16}$.

Table 1. Analytical data and physical properties of the ligand and complexes

\begin{tabular}{cccccc}
\hline \multirow{2}{*}{ Ligand } & \multirow{2}{*}{ Formula } & \multicolumn{4}{c}{ Found (Calcd), \% } \\
\cline { 3 - 6 } & & Carbon & Hydrogen & Nitrogen & Metal \\
\hline $\mathrm{H}_{2} \mathrm{~L}$ & $\mathrm{C}_{26} \mathrm{H}_{24} \mathrm{O}_{6} \mathrm{~N}_{2}$ & $67.2(67.8)$ & $5.01(5.21)$ & $6.10(6.08)$ & -- \\
VOL & {$\left[\mathrm{VO}\left(\mathrm{C}_{26} \mathrm{H}_{22} \mathrm{O}_{6} \mathrm{~N}_{2}\right)\right]$} & $59.50(59.40)$ & $4.20(4.18)$ & $5.19(5.33)$ & $1.69(1.70)$ \\
$\mathrm{MnL} .2 \mathrm{H}_{2} \mathrm{O}$ & {$\left[\mathrm{Mn}\left(\mathrm{C}_{26} \mathrm{H}_{26} \mathrm{O}_{8} \mathrm{~N}_{2}\right)\right]$} & $56.41(56.80)$ & $4.80(4.73)$ & $5.00(5.10)$ & $10.21(10.10)$ \\
$\mathrm{FeL}, 2 \mathrm{H}_{2} \mathrm{O}$ & {$\left[\mathrm{Fe}\left(\mathrm{C}_{26} \mathrm{H}_{26} \mathrm{O}_{8} \mathrm{~N}_{2}\right)\right]$} & $56.63(56.70)$ & $4.75(4.73)$ & $5.10(5.09)$ & $10.20(10.14)$ \\
$\mathrm{CoL}$ & {$\left[\mathrm{Co}\left(\mathrm{C}_{26} \mathrm{H}_{22} \mathrm{O}_{6} \mathrm{~N}_{2}\right)\right]$} & $60.50(60.35)$ & $4.30(4.25)$ & $5.45(5.41)$ & $11.31(11.39)$ \\
$\mathrm{NiL} .2 \mathrm{H}_{2} \mathrm{O}$ & {$\left[\mathrm{Ni}\left(\mathrm{C}_{26} \mathrm{H}_{26} \mathrm{O}_{8} \mathrm{~N}_{2}\right)\right]$} & $56.50(56.46)$ & $4.63(4.70)$ & $5.10(5.07)$ & $10.52(10.60)$ \\
$\mathrm{CuL}$ & {$\left[\mathrm{Cu}\left(\mathrm{C}_{26} \mathrm{H}_{22} \mathrm{O}_{6} \mathrm{~N}_{2}\right)\right]$} & $59.00(59.30)$ & $4.16(4.18)$ & $5.31(5.33)$ & $12.41(12.43)$ \\
$\mathrm{CdL}$ & {$\left[\mathrm{Cd}\left(\mathrm{C}_{26} \mathrm{H}_{22} \mathrm{O}_{6} \mathrm{~N}_{2}\right)\right]$} & $54.61(54.69)$ & $3.79(3.85)$ & $4.90(4.91)$ & $19.81(19.78)$ \\
\hline
\end{tabular}

Table 2. Physical properties of complexes

\begin{tabular}{cccccccc}
\hline Complex & Formula & $\begin{array}{c}\text { m.p } \\
{ }^{\circ} \mathrm{C}\end{array}$ & Geometry & $\begin{array}{c}\text { Molecular } \\
\text { Weight }\end{array}$ & $\begin{array}{c}\% \\
\text { Yield }\end{array}$ & Color & $\begin{array}{c}\text { Magnetic } \\
\text { Moment } \\
(\mathrm{B} . \mathrm{M})\end{array}$ \\
\hline $\mathrm{VOL}$ & {$\left[\mathrm{VO}\left(\mathrm{C}_{26} \mathrm{H}_{22} \mathrm{O}_{6} \mathrm{~N}_{2}\right)\right]$} & $>250$ & $\begin{array}{c}\text { Square } \\
\text { Pyramidal }\end{array}$ & 524.9 & 40 & Brown & 1.70 \\
$\mathrm{MnL} .2 \mathrm{H}_{2} \mathrm{O}$ & {$\left[\mathrm{Mn}\left(\mathrm{C}_{26} \mathrm{H}_{26} \mathrm{O}_{8} \mathrm{~N}_{2}\right)\right]$} & $>260$ & Octahedral & 548.9 & 62 & Brown & 5.56 \\
$\mathrm{FeL}, 2 \mathrm{H}_{2} \mathrm{O}$ & {$\left[\mathrm{Fe}\left(\mathrm{C}_{26} \mathrm{H}_{26} \mathrm{O}_{8} \mathrm{~N}_{2}\right)\right]$} & $>300$ & Octahedral & 549.8 & 60 & Dark red & 5.08 \\
$\mathrm{CoL}$ & {$\left[\mathrm{Co}\left(\mathrm{C}_{26} \mathrm{H}_{22} \mathrm{O}_{6} \mathrm{~N}_{2}\right)\right]$} & $>300$ & tetrahedral & 516.9 & 60 & Dark Green & 4.41 \\
$\mathrm{NiL} .2 \mathrm{H}_{2} \mathrm{O}$ & {$\left[\mathrm{Ni}\left(\mathrm{C}_{26} \mathrm{H}_{26} \mathrm{O}_{8} \mathrm{~N}_{2}\right)\right]$} & $>220$ & Octahedral & 552.6 & 40 & Green & 2.90 \\
$\mathrm{CuL}$ & {$\left[\mathrm{Cu}\left(\mathrm{C}_{26} \mathrm{H}_{22} \mathrm{O}_{6} \mathrm{~N}_{2}\right)\right]$} & $>250$ & $\begin{array}{c}\text { Square } \\
\text { Planar }\end{array}$ & 525.3 & 65 & Black & 1.15 \\
$\mathrm{CdL}$ & {$\left[\mathrm{Cd}\left(\mathrm{C}_{26} \mathrm{H}_{22} \mathrm{O}_{6} \mathrm{~N}_{2}\right)\right]$} & $>300$ & tetrahedral & 570.4 & 62 & Brown & Diamagnetic \\
\hline
\end{tabular}

IR spectral data

The IR spectrum of the ligand shows characteristic frequencies at 1700, 1650, 1231 and a broad trough around $3200-3500 \mathrm{~cm}^{-1}$ centered at $3439 \mathrm{~cm}^{-1}$. These are attributed to $v(\mathrm{C}=\mathrm{O})$, $v(\mathrm{C}=\mathrm{N}), v(\mathrm{C}-\mathrm{O})$ phenolic and $v(\mathrm{OH})$ frequencies.

The IR spectra of the metal complexes exhibit characteristic changes in the functional group frequencies when compared to the spectrum of the ligand. These can be correlated to the specific coordination positions of the ligand. Some additional bands that appear in the spectra of the metal chelates can be correlated to the metal coordinated positions. The position and the intensity of these peaks are expected to change upon chelation. These vibration frequencies are shown in the Table 3. Upon comparison with the ligand characteristic 
frequencies it is determined that the $v(\mathrm{C}=\mathrm{N})$ stretching vibration in complexes underwent a down ward shift by about $35 \mathrm{~cm}^{-1}$ in complexes. The ligand $v(\mathrm{C}=\mathrm{N})$ band at $1650 \mathrm{~cm}^{-1}$ has undergone a shift to lower frequencies, indicating the participation of azomethine nitrogen of $v(\mathrm{C}=\mathrm{N})$ in complexation ${ }^{17}$. The $v(\mathrm{M}-\mathrm{N})$ band appears in the complexes in the range $745-843 \mathrm{~cm}^{-1}$ in different complexes further substantiates the coordination of the azomethine nitrogen in complexation ${ }^{18}$. The $v(\mathrm{C}-\mathrm{O})$ phenolic observed at $1231 \mathrm{~cm}^{-1}$ in the free ligand undergoes an upward shift by about $25-30 \mathrm{~cm}^{-1}$ which indicates the participation of phenolic oxygen of $\mathrm{C}-\mathrm{O}$ in complex formation ${ }^{19,20}$. The non ligand IR frequencies observed in the region of $745-843$ and $665-778 \mathrm{~cm}^{-1}$ are attributed to $v(\mathrm{M}-\mathrm{N})$ and $v(\mathrm{M}-\mathrm{O})$ IR stretching frequencies. A broad trough in the region of $3345-3560 \mathrm{~cm}^{-1}$ is attributed to the $\mathrm{VOH}$ (phenolic) in the free ligand. It undergoes deprotonation and participates in coordination through phenolic oxygen ${ }^{21,22}$. The broad trough observed in the IR spectra of $\mathrm{Mn}$ (II), $\mathrm{Fe}$ (II) and $\mathrm{Ni}(\mathrm{II})$ complexes indicates the presence of coordinated water in these complexes ${ }^{23}$.

Table 3. IR spectral data Schiff base and its various metal complexes

\begin{tabular}{lcccccc}
\hline Ligand/Complex & $\begin{array}{c}v(\mathrm{OH}) \\
\mathrm{cm}^{-1}\end{array}$ & $\begin{array}{c}v(\mathrm{C}=\mathrm{N}) \\
\mathrm{cm}^{-1}\end{array}$ & $\begin{array}{c}v(\mathrm{C}=\mathrm{O}) \\
\mathrm{cm}^{-1}\end{array}$ & $\begin{array}{c}v(\mathrm{C}-\mathrm{O}) \\
\text { Phenolic }\end{array}$ & $\begin{array}{c}v(\mathrm{M}-\mathrm{N}) \\
\mathrm{cm}^{-1}\end{array}$ & $\begin{array}{c}v(\mathrm{M}-\mathrm{O}) \\
\mathrm{cm}^{-1}\end{array}$ \\
\hline $\mathrm{C}_{26} \mathrm{H}_{24} \mathrm{O}_{6} \mathrm{~N}_{2}$ & 3439 & 1650 & 1700 & 1231 & & \\
{$\left[\mathrm{VO}\left(\mathrm{C}_{26} \mathrm{H}_{22} \mathrm{O}_{6} \mathrm{~N}_{2}\right)\right]$} & 3345 & 1642 & 1586 & 1255 & 824 & 739 \\
{$\left[\mathrm{Mn}\left(\mathrm{C}_{26} \mathrm{H}_{26} \mathrm{O}_{8} \mathrm{~N}_{2}\right)\right]$} & 3362 & 1646 & 1553 & 1257 & 745 & 665 \\
{$\left[\mathrm{Fe}\left(\mathrm{C}_{26} \mathrm{H}_{26} \mathrm{O}_{8} \mathrm{~N}_{2}\right)\right]$} & 3562 & 1613 & 1583 & 1253 & 843 & 778 \\
{$\left[\mathrm{Co}\left(\mathrm{C}_{26} \mathrm{H}_{22} \mathrm{O}_{6} \mathrm{~N}_{2}\right)\right]$} & 3446 & 1589 & 1590 & 1238 & 774 & 734 \\
{$\left[\mathrm{Ni}\left(\mathrm{C}_{26} \mathrm{H}_{26} \mathrm{O}_{8} \mathrm{~N}_{2}\right)\right]$} & 3443 & 1614 & 1587 & 1240 & 806 & 701 \\
{$\left[\mathrm{Cu}\left(\mathrm{C}_{26} \mathrm{H}_{22} \mathrm{O}_{6} \mathrm{~N}_{2}\right)\right]$} & 3442 & 1636 & 1591 & 1257 & 750 & 668 \\
{$\left[\mathrm{Cd}\left(\mathrm{C}_{26} \mathrm{H}_{22} \mathrm{O}_{6} \mathrm{~N}_{2}\right)\right]$} & 3422 & 1644 & 1600 & 1257 & 751 & 669 \\
\hline
\end{tabular}

\section{${ }^{1} H$ NMR spectral data}

The ${ }^{1} \mathrm{H}$ NMR spectrum of the ligand 1-[5-(1-\{2-[1-(5-acetyl-2,4-dihydroxy-phenyl)ethylideneamino]phenylimino)-ethyl-2,4-dihydroxy-phenyl]ethanone was recorded in DMSO- $\mathrm{d}_{6}$. The spectrum shows characteristic signals of the ligand in $\delta(\mathrm{ppm})$. A signal at $\delta 0.9$ is due to $\left(\mathrm{S}, 6 \mathrm{H}, \mathrm{CH}_{3} 5^{\prime}\right.$ 'b of RDAP moiety), A signal at $\delta 2.55\left(\mathrm{~s}, 6 \mathrm{H}, \mathrm{CH}_{3} 1\right.$ 'a of RDAP moiety), A signal at $\delta 5.0$ is due to $(\mathrm{s}, 4 \mathrm{H},-\mathrm{OH})$, A signal at $\delta 6.38$ is due to $(\mathrm{s}, 2 \mathrm{H}$, $\mathrm{C}_{3} \mathrm{H}$ of benzyliden imine proton), a signal at $\delta 7.3$ (s,4H, aromatic protons of $o$-phenylenediamine moiety) a signal at $\delta 7.88$ is due to $\left(\mathrm{s}, 2 \mathrm{H} \text {, benzylidene imine protons on } \mathrm{C}_{6} \mathrm{H}\right)^{24}$. All the signals correlate very well with the proposed structure of the ligand ${ }^{25}$.

\section{${ }^{13}$ C NMR spectrum of the ligand}

The ${ }^{13} \mathrm{C}$ NMR spectrum of the ligand was recorded in DMSO- $\mathrm{d}_{6}$ using TMS as standard. The spectrum shows its characteristic frequencies. A signal at $\delta 16.3$ is due to the carbon of $\mathrm{CH}_{3}$ group attached to $\mathrm{C}=\mathrm{N}$ group. A signal at $\delta 29.6$ is due to $\mathrm{CH}_{3}$ of acetyl group. A signal at $\delta 78$ is due to $\mathrm{C}_{3}$ carbon of RDAP moiety. A signal at $\delta 11.3$ is due to the aromatic carbon attached to azomethine carbon. A signal at $\delta 114.6$ is due the aromatic carbon attached to the $\mathrm{CH}_{3} \mathrm{CO}$ group of RDAP moiety. Signals at $\delta 123.6$ and $\delta 128.6$ are due to the aromatic carbons of phenylene group. A signal at $\delta 130.9$ is due to aromatic carbon of the RDAP moiety. A signal at $\delta 144.8$ is due to the aromatic carbon of OPD attached to the azomethine group. Signals at $\delta 164.4$ and $\delta 166.9$ are due to the aromatic carbons attached to-OH groups. A signal at $\delta 165.2$ is due to the azomethine carbon. A signal at $\delta 199.8$ is due to carbon of $\mathrm{CH}_{3}$ of $\mathrm{CH}_{3} \mathrm{C}=\mathrm{O}$ group. The ${ }^{13} \mathrm{C}$ NMR spectral peaks explain the expected structure of the ligand. 


\section{Mass spectrum}

ESI mass spectrum of the ligand shows a base peak at $\mathrm{m} / z, 479\left(\mathrm{M}+\mathrm{NH}_{4}{ }^{+} \pm 1\right)$. It shows various fragments at $\mathrm{m} / \mathrm{z} 465, \mathrm{~m} / \mathrm{z}, 442, \mathrm{~m} / \mathrm{z}, 421, \mathrm{~m} / \mathrm{z} 382$ and $\mathrm{m} / \mathrm{z} 363$ corresponding to various fragments of the ligand as shown in the Figures 2-9. The mass spectrum very well matches with the expected structure of the ligand.

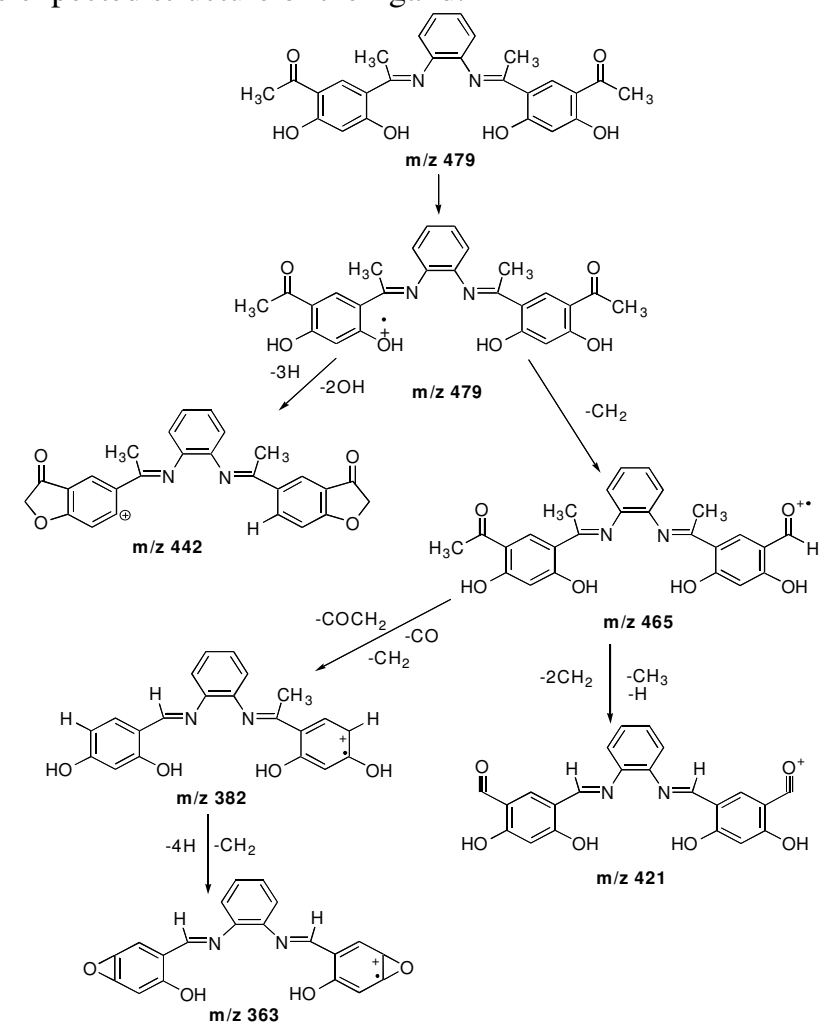

Figure 2. Mass fragmentation of the ligand

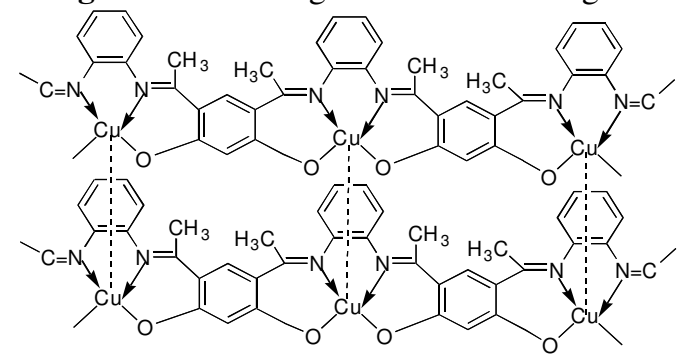

Figure 3. $\mathrm{Cu}(\mathrm{II})$ complex in square planar geometry

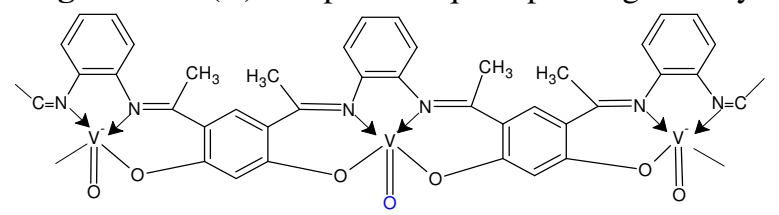

Figure 4. VO(IV) complex in square pyramidal geometry 


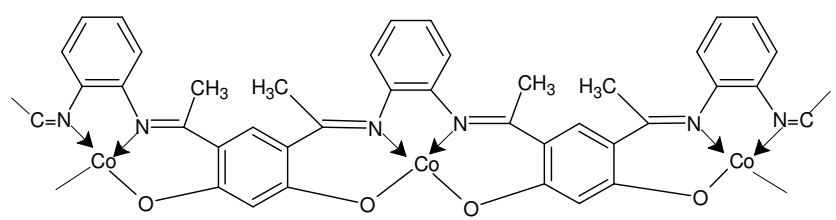

Figure 5. Co(II) complex in pseudo tetrahedral geometry

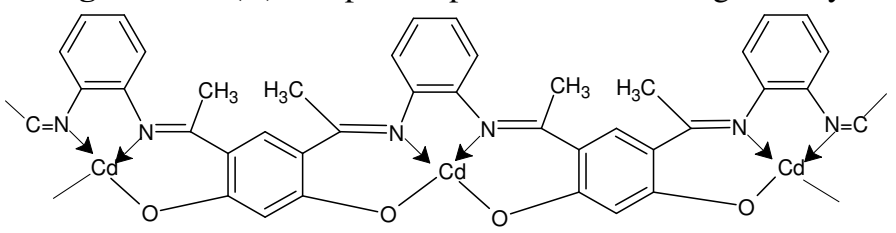

Figure 6. $\mathrm{Cd}(\mathrm{II})$ complex in pseudo tetrahedral geometry

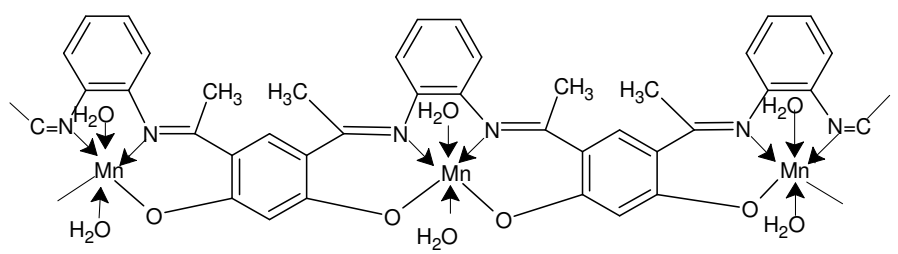

Figure 7. $\mathrm{Mn}$ (II) complex in octahedral geometry

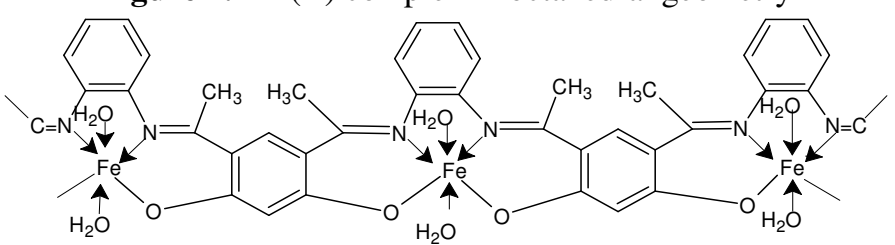

Figure 8. Fe(II) complex in octahedral geometry

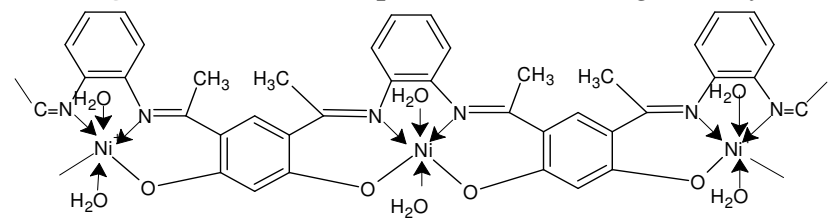

Figure 9. $\mathrm{Ni}(\mathrm{II})$ complex in octahedral geometry

\section{Electronic spectra of metal complexes}

The electronic spectrum of the vanadyl complex shows three absorption bands at 13300, 17390 and $21280 \mathrm{~cm}^{-1}$. These are assigned to ${ }^{2} \mathrm{E} \leftarrow{ }^{2} \mathrm{~B}_{2} ;{ }^{2} \mathrm{~B}_{1} \leftarrow{ }^{2} \mathrm{~B}_{2}$ and ${ }^{2} \mathrm{~A}_{1} \leftarrow{ }^{2} \mathrm{~B}_{2}$ transitions .So the complex can be assigned to square pyramidal geometry. ${ }^{26}$ The UV Visible near IR spectrum of the $\mathrm{Mn}$ (II) complex shows weak absorptions in the region 15000, 20200, 23600, 26400, 31000, 33000 and $37700 \mathrm{~cm}^{-1}$ These are assigned to spin forbidden transitions ${ }^{4} \mathrm{~T}_{1 \mathrm{~g}} \leftarrow{ }^{6} \mathrm{~A}_{1 \mathrm{~g}}$; ${ }^{4} \mathrm{~T}_{2 \mathrm{~g}} \leftarrow{ }^{6} \mathrm{~A}_{1 \mathrm{~g}} ;{ }^{4} \mathrm{~A}_{1 \mathrm{~g}} \leftarrow{ }^{6} \mathrm{~A}_{1 \mathrm{~g}} ;{ }^{4} \mathrm{E}_{\mathrm{g}}(\mathrm{G}) \leftarrow{ }^{6} \mathrm{~A}_{1 \mathrm{~g}} ;{ }^{4} \mathrm{~T}_{2 \mathrm{~g}}(\mathrm{D}) \leftarrow{ }^{6} \mathrm{~A}_{1 \mathrm{~g}} ;{ }^{4} \mathrm{~T}_{1 \mathrm{~g}}(\mathrm{P}) \leftarrow{ }^{6} \mathrm{~A}_{1 \mathrm{~g}}$ and ${ }^{4} \mathrm{~A}_{2 \mathrm{~g}}(\mathrm{~F}) \leftarrow{ }^{6} \mathrm{~A}_{1 \mathrm{~g}}$ transitions respectively. Based on the spectral data it can be assigned to the octahedral geometry $^{27}$. The electronic absorption spectrum to the Fe(II) complex of the ligand shows absorption at $10200 \mathrm{~cm}^{-1}$ and at $37700 \mathrm{~cm}^{-1}$. The first absorption is interpreted to the ${ }^{5} \mathrm{E}_{\mathrm{g}} \leftarrow{ }^{5} \mathrm{~T}_{2 \mathrm{~g}}$ and the other one is due to charge transfer transition. On the basis of the absorption band, the $\mathrm{Fe}(\mathrm{II})$ complex has been proposed an octahedral geometry ${ }^{28}$. 
The UV Visible spectrum of the Co(II) complex shows its characteristic absorption bands at $6500 \mathrm{~cm}^{-1}$ and $13875 \mathrm{~cm}^{-1}$. These are assigned to pseudo tetrahedral geometry, ${ }^{4} \mathrm{~T}_{1} \leftarrow{ }^{4} \mathrm{~A}_{2}$ and ${ }^{4} \mathrm{~T}_{1}(\mathrm{P}) \leftarrow{ }^{4} \mathrm{~A}_{2}$ transitions respectively ${ }^{29}$. The electronic spectrum of the Ni(II) complex shows absorption bands at 11700,18350 and $29000 \mathrm{~cm}^{-1}$. These are interpreted to ${ }^{3} \mathrm{~T}_{2 \mathrm{~g}} \leftarrow{ }^{3} \mathrm{~A}_{2 \mathrm{~g}} ;{ }^{3} \mathrm{~T}_{1 \mathrm{~g}} \leftarrow{ }^{3} \mathrm{~A}_{2 \mathrm{~g}}$ and ${ }^{3} \mathrm{~T}_{1 \mathrm{~g}}(\mathrm{P}) \leftarrow^{3} \mathrm{~A}_{2 \mathrm{~g}}$. Based on these assignments the complex has been proposed with an octahedral geometry ${ }^{30}$. The UV Visible spectrum of the $\mathrm{Cu}$ (II) complex shows a broad absorption band with multiple structures in the region $13000-20000 \mathrm{~cm}^{-1}$. This has been assigned to ${ }^{2} \mathrm{~B}_{2} \leftarrow{ }^{2} \mathrm{E}$; ${ }^{2} \mathrm{~A}_{1} \leftarrow{ }^{2} \mathrm{E}$ and ${ }^{2} \mathrm{~B}_{1} \leftarrow{ }^{2} \mathrm{E}$ transitions. The electronic absorption spectrum suggests a square pyramidal geometry with a metal bonding in the solid state. The antiferromagnetic interaction between the two metal centres is supported by the subnormal magnetic moments ${ }^{31}$. The electronic spectrum of the Cd(II) complex shows no $d-d$ transitions as it belongs to a $\mathrm{d}^{10}$ system. The absorptions observed at $40000,42000 \mathrm{~cm}^{-1}$ suggest that it exhibits metal ligand charge transfer transitions. The complex has been proposed with a pseudo tetrahedral geometry.

\section{Magnetic data of the complexes}

The magnetic susceptibilities of the complexes have been determined at room temperature. The spin only magnetic moments of the complexes have been calculated in Bohr Magnetons. The oxovanadium(IV) complex exhibits a magnetic moment of 1.69 B.M. This is in correlation with the spin only magnetic moment obtainable for these complexes with a single unpaired electron. Hence the complex has been proposed a five coordinated square pyramidal stereochemistry. The Ni(II) complexes with magnetic moment 2.9 B.M suggests octahedral geometry $^{32}$. The $\mathrm{Mn}$ (II) complex shows a magnetic moment of 5.6B.M .This value is almost near to the spin only magnetic moment value of typical $\mathrm{Mn}$ (II) complexes. This shows that the complex can be assigned with an octahedral geometry ${ }^{33}$. The Fe(II) complex of the ligand shows a magnetic moment value of 5.08 B.M. The value is near to the spin only magnetic moment value of 4.90 B.M for the $\mathrm{Fe}(\mathrm{II})$ complexes. Hence the complex has been proposed with an octahedral stereochemistry around the metal with $\mathrm{N}$ : $\mathrm{N}$ : O: O donor sequence of the ligand and two $\mathrm{H}_{2} \mathrm{O}$ water molecules coordinating in the axial position.

The Co(II) complex shows a magnetic moment of 4.0 B.M. This value is close to the magnetic moment value of the tetrahedral Co(II) complexes. (3.87 B.M.) So the complex has been proposed with tetrahedral geometry ${ }^{34}$. The $\mathrm{Cu}(\mathrm{II})$ complex exhibits a subnormal magnetic moment of 1.15 B.M. This value is expected for the complexes with metal-metal interactions. The value reveals an antiferromagnetic coupling between the two $\mathrm{Cu}$ (II) centres. So based on these results the complex has been interpreted to square pyramidal geometry ${ }^{35}$. The $\mathrm{Cd}$ (II) complex shows diamagnetism. The complex has been proposed with a pseudo tetrahedral geometry.

\section{Biological activity}

The ligand and its various complexes formed from VO(IV), Mn(II), $\mathrm{Fe}(\mathrm{II}), \mathrm{Co}(\mathrm{II}), \mathrm{Ni}(\mathrm{II})$, $\mathrm{Cd}(\mathrm{II})$ and $\mathrm{Cu}(\mathrm{II})$ have been dissolved in DMSO in $100 \mu \mathrm{g} / \mathrm{mL}$ concentrations. The complexes and ligand dissolved in DMSO $(100 \mu \mathrm{g} / \mathrm{mL})$ were added to a potato dextrose agar (PDA) and were then poured into sterile Petri dishes $(9 \mathrm{~cm}$. in diameter) and were left to solidify. Using a cork borer (6 $\mathrm{mm}$ in diameter), Aspergillus terreus spores were suspended on the medium at the centre. Finally the dishes were incubated at $37{ }^{\circ} \mathrm{C}$ for $72 \mathrm{~h}$ and the treated Petri dishes were compared with controlled Petri plates. Clear inhibition was noticed with the ligand and complexes where the DMSO solutions were added. This experiment was carried out in triplicates. It was noticed that the copper complex has shown the highest inhibition followed by other complexes and the ligand (Table 4 \& Figure 10). The percentage inhibition of the bacteria was calculated by the following equation: 


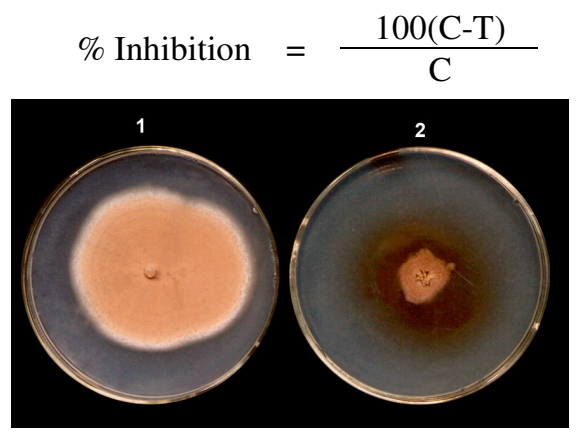

Figure 10

Where $\mathrm{C}$ is the diameter $(\mathrm{mm})$ in controlled plates after $72 \mathrm{~h}$ and $\mathrm{T}$ is the diameter in $\mathrm{mm}$ in treated plates after $72 \mathrm{~h}$. The order of percentage inhibition has been observed to be $\mathrm{Cu}(\mathrm{II})>\mathrm{Cd}(\mathrm{II})>\mathrm{Co}(\mathrm{II})>\mathrm{VO}(\mathrm{IV})>\mathrm{Fe}(\mathrm{II})>\mathrm{Ni}$ (II) $>\mathrm{Mn}$ (II) $>$ Ligand .

Table 4. Biological activity of the ligand and metal complexes

\begin{tabular}{lcc}
\hline Formula of the & Inhibition with $100 \mu \mathrm{g} / \mathrm{mL}$ & Inhibition with $500 \mu \mathrm{g} / \mathrm{mL}$ \\
ligand/complex & $\%$ & $\%$ \\
Ligand & 9 & 12 \\
VO(IV) complex & 24 & 29 \\
Mn(II) complex & 21 & 24 \\
Fe(II) complex & 23 & 27 \\
Co(II) complex & 59 & 73 \\
Ni(II) complex & 22 & 26 \\
Cu(II) complex & 69 & 89 \\
Cd(II) complex & 62 & 76 \\
\hline
\end{tabular}

\section{Conclusion}

On the basis of the analytical data, IR spectral data, electronic spectral analysis, Magnetic moment data and also on the geometry of the ligand, it is proposed that $\mathrm{Mn}$ (II), $\mathrm{Fe}$ (II) and $\mathrm{Ni}(\mathrm{II})$ complexes have been assigned with an Octahedral stereochemistry. $\mathrm{The} \mathrm{Cu}(\mathrm{II})$ and $\mathrm{VO}(\mathrm{IV})$ complexes have been proposed with a square pyramidal geometry. The $\mathrm{Co}(\mathrm{II})$ and $\mathrm{Cd}(\mathrm{II})$ complexes have been interpreted with a pseudo tetrahedral geometry.

\section{Acknowledgment}

One of the authors Mrs. Ammanni is thankful to St. Ann's College for women for providing financial assistance. We are also thankful to Dr.B. Sreedhar, IICT for IR, NMR, Mass spectral analysis. We show our gratitude to Head, Department of Chemistry, Osmania University for providing facility to carry out magnetic susceptibility measurements. We are grateful to Prof. Nagamani, Department of Botany, P.G.College of Science, Saifabad in guiding us to carryout antifungal studies.

\section{References}

1. Fenton D E, In A.G. Sykes (Ed), Advances in Inorganic and Bioinorganic mechanisms, Academic Press, London, 1983, 2, 187

2. Guerriero P, Vigato P A, Fenton D E and Hellier P C, Acta Chem Scand., 1992, 46, 1025. 
3. Lussac D, Savariauli J M, Cassou P C and Tuchangues J P, J Chem Soc Dalton Trans., 1988, 1225.

4. Muralidhar Reddy P, Ashok M, Usha Rani P and Ravindran V, Int J Chem Sci., 2007, (5)2, 489-495.

5. Karvembu R, Hemalatha S, Prabhakaran R and Natrajan K, Inorg Chem Commun., 2003, 6, 486-490.

6. Daniel T Thangaduri and Natrajan K, Trans Met Chem., 2002, 27, 485.

7. Frey G D, Bell Z R, Jeffery J C and Ward M D, Polyhedron, 2001, 20, 3231.

8. Mevellec F, Collet S, Deniand D, Reliquet A and Meslin J C, J Chem Soc Perkin Trans., 2001, 1, 3128.

9. $\quad$ Sid S D, Baitich O B and Dolume J P, J Mol Struct., 2001, 569, 121.

10. Karidi K, Garoufis A, Tsipis A, Hadjiliads N, Dulk H and J Reedijk, J Chem Soc Dalton Trans, 2005, 1176.

11. Akbayera D N, Gonsalvi L, Oberhouser W, Peruzzini M, Vizza F, Biuggeller P, Ramerosa and Sava G, Bergamo Chem Commun., 2003, 264.

12. $\quad \mathrm{Wu} \mathrm{J} Z$ and Yuan, L, J Inorga Biochem., 2004, 98(1), 41-45.

13. Dwyer F B, Mayhew E, Roe E M F and Shulman A, Br J Cancer, 1965, 19, 195-199.

14. Vogel's text book of Practical Organic Chemistry, Longmans, London, $5^{\text {th }}$ Ed., 1989.

15. Anjeneyulu A S R, Ramaprasad A V and Shiva Kumar Reddy D, Current Sci., 1979, 48, 300.

16. Reddy P M, Ashok M, Rani P U and Ravinder V, Int J Chem Sci., 2007, 5(2), 953-959

17. Soliman A A and Linert W, Thermochemica Acta, 1999, 333, 67-75.

18. Bellamy L J, The Infrared Spectra of Complex Molecules, Chapman and Hall, London, Vol II, $2^{\text {nd }}$ Ed., 1980.

19. Biradar N S and Kulkarni V H P, J Inorg Nucl Chem., 1971, 33(11), 3781-3786.

20. Ruddick J N R and Sams J R, J Organomet Chem., 1973, 60, 233.

21. Sarawat S, Srivastava G.S and Mehrotra R C, J Organomet Chem., 1977, 129, 155-161.

22. Gruber S J, Harris C M and Sinn E, J Inorg Nucl Chem.. 1968, 30, 1805.

23. Nakamoto K, Infrared spectra of Inorganic and Coordination Compounds, WileyInterscience, New york, 1970, 159, 167, 214.

24. Qayyoom M A, Hanumanthu P and Ratnam C V, Indian J Chem., 1982, 21B, 883.

25. William Kemp, Organic spectroscopy, ELBS, Mac millan Hampshire, 1987, 105-107.

26. Howlader M B H, Islam M S and Karim M R, Indian J Chem., 2000, 39A, 407.

27. Lever A B P, Inorganic Electronic Spectroscopy, Elsevier, 1984, $2^{\text {nd }}$ Ed., 469.

28. Chaudhary K R, Keshari B N and Mishra L K, J Indian Chem Soc., 2000, 77, 29.

29. Lever A B P, Inorganic Electronic Spectroscopy, Elsevier, $2^{\text {nd }}$ Ed., 1984, 499.

30. Raman N, Ravichandran S and Thangaraja C, J Chem Sci., 2004, 116(4), 215-219.

31. Shehad A. Sallam, Transition Metal Chem., 2005, 30, 341-351.

32. Abdou Saad El-Tabl, Transition Metal Chem., 2002, 27, 166-170.

33. Neelamma M, Venkateswara Rao P and Jyothi V, Int J Pure Appl Chem., 2007, 2(1), 127-133,

34. Amali Roseline Emelda, Jaya Chandramani and Ravi Chandran S, Int J Chem Sci., 2007, 5(2), 509-514.

35. Patel B V, Desai K and Thaker T, Synth React Inorg Met Org Chem., 1989, 19, 391. 


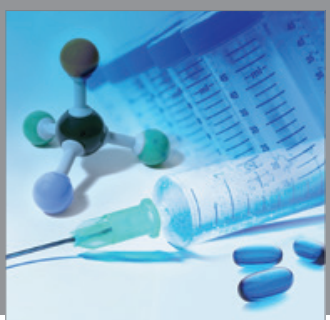

International Journal of

Medicinal Chemistry

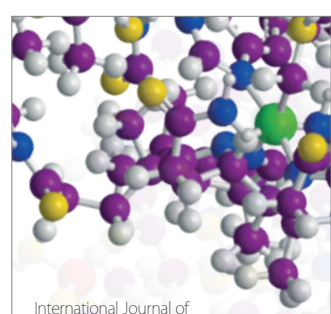

Carbohydrate Chemistry

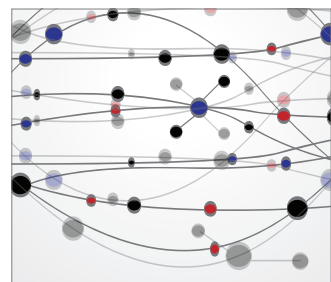

The Scientific World Journal
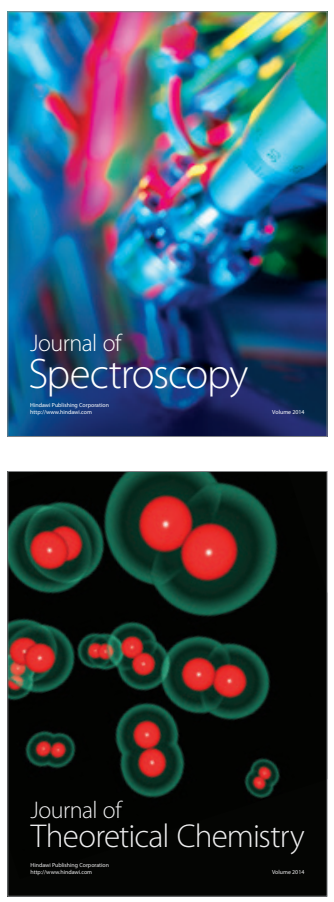
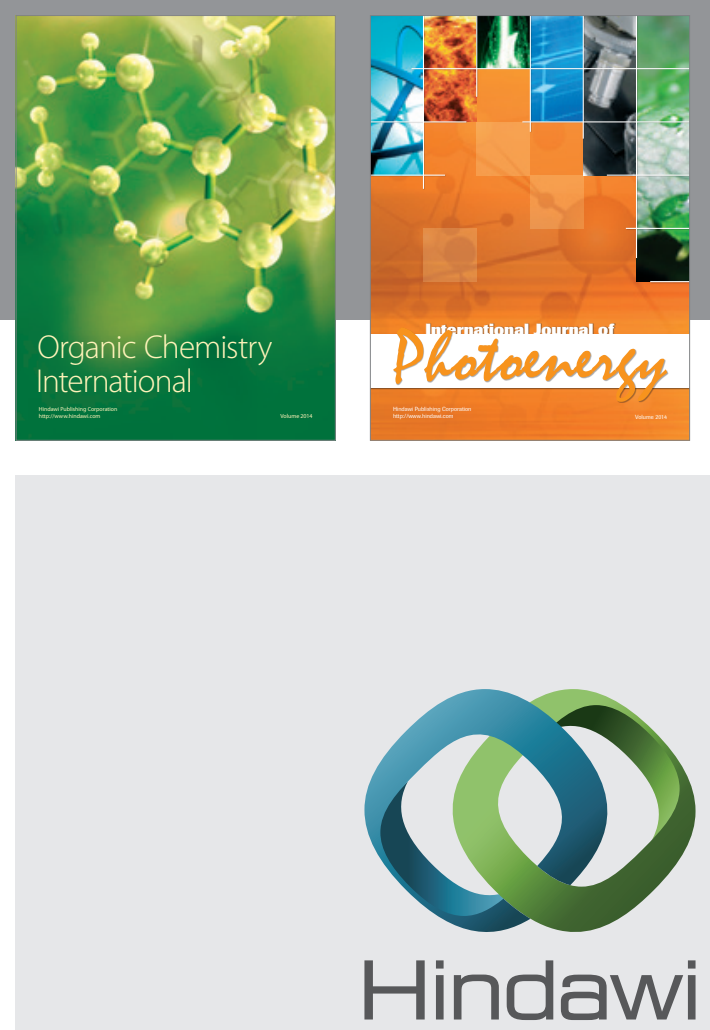

Submit your manuscripts at

http://www.hindawi.com
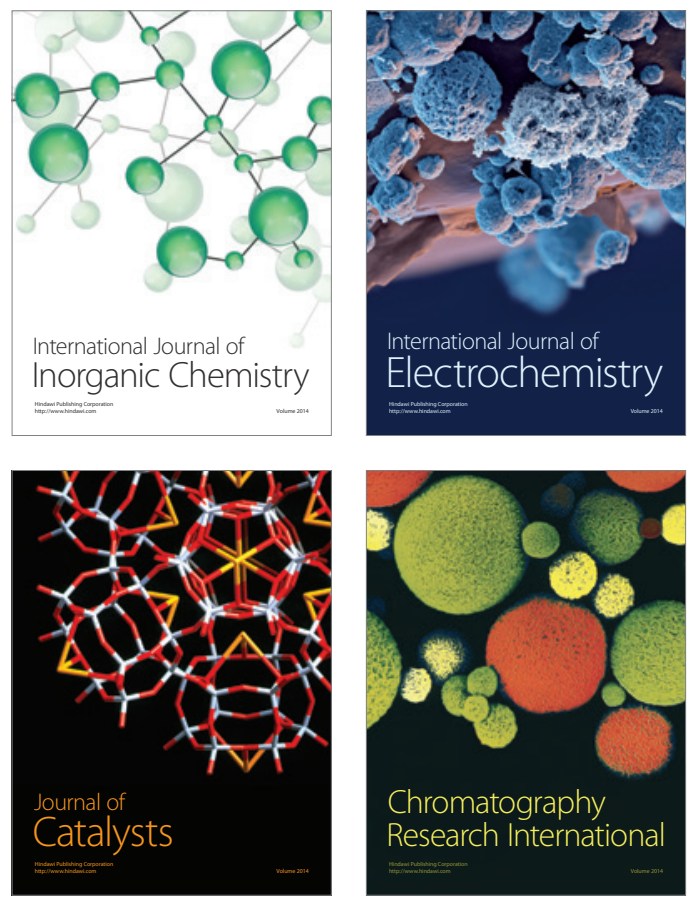
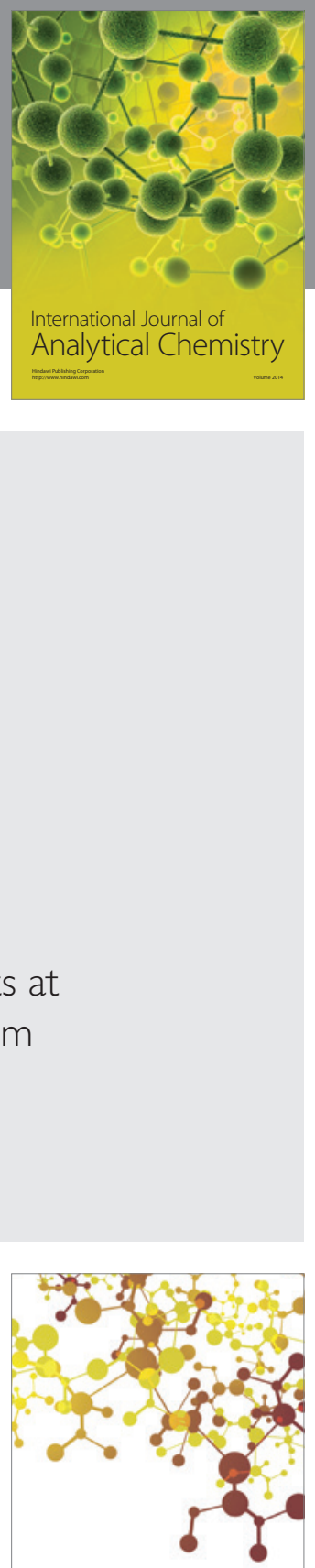

Journal of

Applied Chemistry
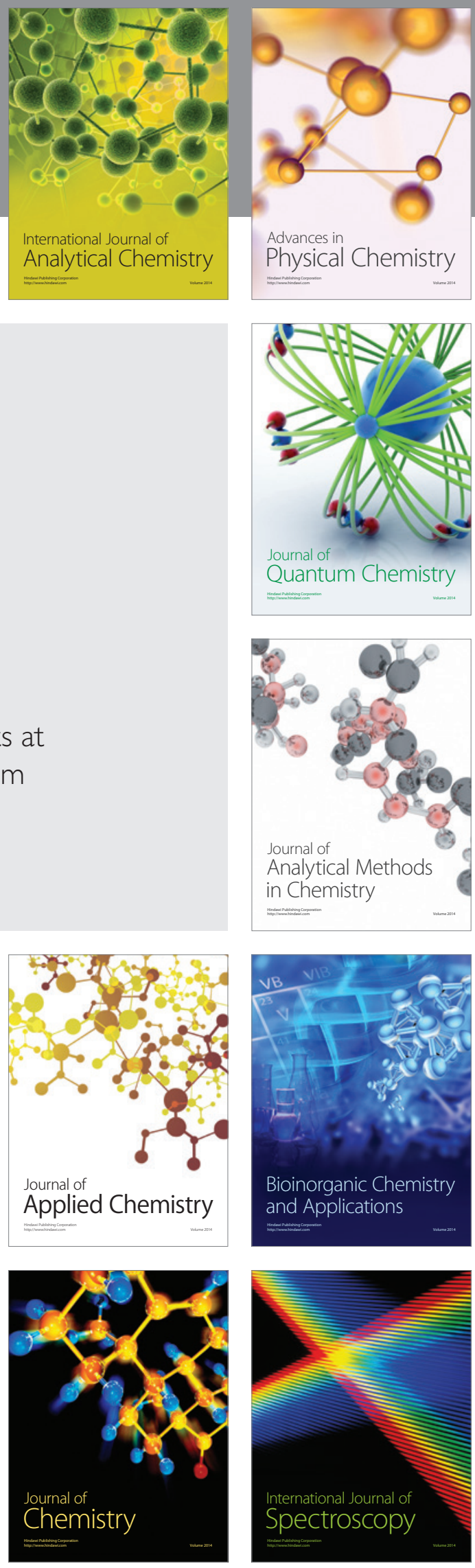